\title{
Performance and feed intake of beef heifers on rotational grazing of natural grassland receiving protein and energy supplement in cool season
}

\author{
Bruno Castro Kuinchtner ${ }^{*} \cdot$ Fernando Luiz Ferreira de Quadros $^{2}$ Felipe Jochims ${ }^{3}$ \\ Pedro Trindade Casanova ${ }^{4}$ Gabriela Machado Dutra ${ }^{4}$ \\ Fernando Ongaratto ${ }^{4}$ Régis Maximiliano Roos de Carvalho ${ }^{4}$
}

\begin{abstract}
${ }^{1}$ Laboratório de Ecologia de Pastagens Naturais (LEPAN), Universidade Federal de Santa Maria (UFSM), 97105-900, Santa Maria, RS, Brasil. E-mail: brunobck@hotmail.com. ${ }^{*}$ Corresponding author.

${ }^{2}$ Departamento de Zootecnia, Centro de Ciências Rurais (CCR), Universidade Federal de Santa Maria (UFSM), Santa Maria, RS, Brasil.

${ }^{3}$ Empresa de Pesquisa e Extensão Rural de Santa Catarina (Epagri), Centro de Pesquisa para Agricultura Familiar (Cepaf), Chapecó, SC, Brasil.

${ }^{4}$ Programa de Pós-graduação em Zootecnia (PPGZ), Universidade Federal de Santa Maria (UFSM), Santa Maria, RS, Brasil.
\end{abstract}

\begin{abstract}
The aim of this study was to evaluate the performance and feed intake of grazing beef heifers on two grazing intervals determined by thermal sum related to leaf elongation duration during cool season on natural grasslands. A complete randomized block design experiment with two treatments and three replications was conducted from May to September 2011 in the central part of the state of Rio Grande do Sul, Brazil. The treatments were two thermal sums calculated at 375 and 750 degrees-days (DD) to determine the intervals between grazing periods in a rotational grazing system. Thirty six beef heifers with average age of 18 months old and (initial body weight $=220 \pm 14 \mathrm{~kg}$ ) were used, all heifers received ground corn supplement at a rate of $5 \mathrm{~g} \mathrm{~kg}^{-1}$ of body weight per day, at $2 \mathrm{p} . \mathrm{m}$., throughout the experiment and had free access to mineral and protein supplementation (450 $\mathrm{kg}^{-1}$ of $C P$ ). Similar average daily gain (ADG), beef production gain (BPG) and feed intake (FI), were obtained in both treatments. Leaf elongation duration is an alternative grazing management tool for improved animal production and to increase animal stocking rate.
\end{abstract}

Key words: animal production, beef heifers rearing, grazing system.

Desempenho de bezerras de corte em pastoreio rotativo em pastagem natural recebendo suplemento proteico-energético

RESUMO: Objetivou-se avaliar o desempenho e consumo de matéria seca de bezerras manejadas em pastoreio rotativo, com intervalos de pastoreio definidos por duas somas térmicas relacionadas à duração de elongação foliar de dois grupos funcionais de gramíneas durante a estação fria em pastagem natural. O delineamento experimental foi o de blocos completamente casualizados, com dois tratamentos e três repetições de área na região central do Rio Grande do Sul, Brasil. Os tratamentos foram duas somas térmicas: 375 e 750 graus-dias (GD), que determinaram os intervalos entre os pastoreios. Foram utilizadas trinta e seis bezerras de corte com idade média de 18 meses e peso corporal médio de $220 \pm 14 \mathrm{~kg}$. Durante todo o experimento, as bezerras receberam como suplemento grão de milho moído a uma taxa de 0,5\% do peso corporal por dia, às 14:00 horas e tiveram livre acesso à suplementação proteínada (45\% PB). Não houve diferença para o ganho médio diário, ganho de peso por área e consumo de matéria seca entre os tratamentos. A soma térmica como intervalo de descanso entre os pastoreios mostrou-se uma alternativa de manejo para aumentar a taxa de lotação.

Palavras-chave: pastagem natural, graus-dia, suplemento, produção animal.

\section{INTRODUCTION}

South America natural grasslands include all Uruguay, northeast Argentina, south Brazil and part of the Paraguay. In Brazil, these natural grasslands are located in the southern region and encompasses two biomes. According to the national classification (IBGE, 2004), the grasslands situated in the northeast region of Rio Grande do Sul, Santa Catarina and Paraná states belong to Mata Atlântica biome and the grasslands situated in the southern part of Rio Grande do Sul state are called Pampa biome.

Pampa biome represents $2.07 \%$ $\left(176.496 \mathrm{Km}^{2}\right)$ of Brazilian territory (IBGE, 2004) and, currently, still remain $23 \%\left(41.054,61 \mathrm{Km}^{2}\right)$ of its natural vegetation, mainly grasslands, without anthropic modification (HASENACK et al., 2010). It is important to define appropriate management strategies for specific grazing systems (HODGSON \& DA SILVA, 2000); however, grasslands with high 
species biodiversity, as observed in the Pampa biome, renders grazing management difficult and becomes almost impossible to prioritize only one aspect (e.g. animal, plant and soil) making necessary a holistic system approach.

To facilitate natural grassland management evaluation for optimal animal production and conservation, CRUZ et al. (2010) simplified the grass species diversity clustering functional groups with similar specific leaf area and leaf dry matter content. Similarly, QUADROS et al. (2011) suggested as a grazing management tool the using these functional groups of the main native grasses based in its ecophysiological traits, these traits are linked to thermal sum necessary to turn on physiological process.

The use of thermal sum in degree-days (DD) is defined as the sum across days of the average between maximum and minimum temperature within a day (OMETTO, 1981), it may be in near real-time as a grazing management tool (i.e. calculating DD according to ambient temperature on a day per day basis) would allow accounting for the effects of actual environmental conditions and specific characteristics of plant functional groups. The thermal sum could be a tool to measure on farm and has the potential to improve grazing management as it determines permanence time and length of grazing intervals for each specific grazing system QUADROS et al. (2011).

The present study aimed to evaluate heifer's performance and feed intake throughout the cool season using two different grazing intervals based in the thermal sum of the main native forage species on natural grassland.

\section{MATERIALS AND METHODS}

The experiment was conducted from May to September (2011) in a natural grassland, located at Depressão Central region, in Rio Grande do Sul state, Brazil. The area is situated in the coordinates (2943'29.97'S, 5345'36.91'W), $95 \mathrm{~m}$ above sea level and subtropical humid climate (Cfa) according to Köppen classification. In the area there are two soil types: Typic Albaqualf on lowland areas and Rhodic Paleudalf on top and slope areas. During the trial, the mean of the minimum and maximum temperatures were, respectively, $10.6^{\circ} \mathrm{C}$ and $20.4^{\circ} \mathrm{C}$ and the mean precipitation was $102 \mathrm{~mm}$ per month. Experimental procedures were conducted in accordance with the Ethics Committee on Animal Use of Universidade Federal de Santa Maria.

Treatments consisted of two different thermal sums, 375 and 750 degree-day (DD), related to leaf elongation duration of contrasting grasses functional groups. The $375 \mathrm{DD}$ is the interval necessary for the elongation of 2.5 leaves of Axonopus affinis and Paspalum notatum, which are prostrate $\mathrm{C}_{4}$ grasses of the functional groups A and B (QUADROS et al., 2006), with an average phyllochron of $150 \mathrm{DD}$ (EGGERS et al., 2004; MACHADO et al., 2013). The 750 DD represent the time for elongation of 2.2 leaves for tufted grasses from functional groups $\mathrm{C}$ and $\mathrm{D}$, as Aristida laevis and Saccharum angustifolius, with phyllochron of 333 DD (MACHADO et al., 2013; CONFORTIN et al., 2010).

The occupation time of each paddock (grazing cell) was a function of rest time (between the grazing periods) according to the following formula:

$$
\text { Occupation }(\text { degree-days })=\frac{\text { Resting period }(D D)}{\text { Nro. paddocks }-1}
$$

Where DD is the treatment (375 or 750 DD), 1 is the paddock in use, and Nro. paddocks are either 6 or 8 for the 375 and 750 DD treatments, respectively. For $375 \mathrm{DD}$, it ranges from 4 to 7 occupation days, with mean of 5.1 and for $750 \mathrm{DD}$, it ranges from 6 to 11 occupation days, with mean of 7.9 days. During the trial, in 375 DD treatment held 4 cycles (26.2 days each cycle) in the pasture. In 750 DD, 1.8 cycles ( 60 days by cycle).

Both treatments were managed with constant stocking rate and variable herbage allowance subjected to rotational grazing. A paddock (0.5 ha) was selected in each replicate (representative paddock) for all the pasture measurements.

The trial lasted for 113 consecutive days and was divided into four periods: May, $26^{\text {th }}$ to June $24^{\text {th }}$ (period 1$)$; June, $24^{\text {th }}$ to July $22^{\text {th }}$ (period 2); July $22^{\text {th }}$ to August 20 $0^{\text {th }}$ (period 3) and August $20^{\text {th }}$ to September $16^{\text {th }}$ (period 4$)$.

A complete randomized block design was employed, with two treatments and three replicates. The experimental area had 21 ha divided into six replicates (experimental units) randomly assigned to the 2 treatments with 3 replicates each. In treatment $375 \mathrm{DD}$, each replicate was subdivided in six cells (paddocks) whereas in the $750 \mathrm{DD}$ treatment the replicates were divided in eight cells (paddocks) for animal rotation. In total, 42 grazing cells (paddocks) with 0.5 ha each were used and all were provided with fresh water ponds.

Thirty six beef heifers of approximately 18 months of age with an average initial body weight of $220 \pm 14 \mathrm{~kg}$, were distributed as six animal into replicate. All heifers received daily supplementation at 2:00p.m. at 
a rate of $50 \mathrm{~g} \mathrm{~kg}^{-1} \mathrm{~d}^{-1}$ of body weight mean of each replicate of ground corn. They also had protein supplement (450 $\mathrm{g} \mathrm{kg}^{-1}$ of crude protein from urea) allowed for adlibitum consumption., Sanitary management was made when necessary with pour-on (Fluazuron or Fipronil) sprinkling shower (Amitraz), and vaccination as required (endoparasite, clostridium sp.)

Herbage mass (HM; $\mathrm{kg} \mathrm{ha}^{-1}$ of dry matter (DM)) was measured using a direct comparison to standards calibrated with double-sampling technique (HAYDOCK; SHAW, 1975), where six samples $(0.5 \times 0.5 \mathrm{~m})$ were cut at the ground level and 20 visual estimations were done in the representative paddock for each replicate.

Removed biomass from cut samples was divided into 2 subsamples and weighed, one subsample was used to determine DM content, dried in a forced air oven at $55^{\circ} \mathrm{C}$ for at least 72 hours and another subsample was used to separate morphological components (green leaf lamina, pseudo stem and dead material). Herbage allowance ( $\mathrm{kg} \mathrm{DM} 100 \mathrm{~kg}^{-1}$ of body weight) was calculated using the mean of leaf lamina contribution in the HM in each period of the rotational, divided by the number of occupation days and divided by the instantaneous stocking rate, multiplied by 100 . Mean leaf lamina contribution were calculated using the percentage of green leaf lamina material, from available morphological components of the representative paddock.

Instantaneous stocking rate (ISR) was calculated as the sum of all animals' body weight in an experimental group divided by the paddock area in use. Mean stocking rate (MSR; $\mathrm{kg} \mathrm{ha}^{-1}$ of body weight) was calculated as ISR divided by replicate (all paddocks per block) area. Beef production gain per area (BPA; $\mathrm{kg}$ $\mathrm{BW} \mathrm{ha}^{-1}$ ) was calculated as number of animals per area multiplied by average daily gain (ADG) and number of days per period. The animals were weighed each 28 consecutive days, after a total fasting period of at least 12 hours, mean ADG calculated. The ADG was the difference of body weight between 2 consecutive weighs divided by the number of days between measurements.

In situ organic matter degradability (ISOMD) of the ground corn and hand-plucked samples of herbage, similar to that selected by the animals were determined according to Orskov and Mc Donald (1979) and hand-plucked was collected according to EUCLIDES et al. (1992). Samples were collected when the animals were on the second day of occupation in both treatments. The hand plucking samples were also analyzed for total $\mathrm{DM}$ in an oven at $105^{\circ} \mathrm{C}$ for 24 hours, total nitrogen $(\mathrm{N}$; $\mathrm{N} \times 6.25=$ crude protein; AOAC, 1990) and neutral and acid detergent fiber without amylase (VAN SOEST, 1967).
Herbage intake estimates was taken on two occasions (July $9^{\text {th }}$ and September 12 $2^{\text {th }}$, 2011; second and last periods above described), representing autumn and winter seasons, respectively. Two animals per replicate were evaluated, using $\mathrm{Cr}_{2} \mathrm{O}_{3}$ as an external marker for determination of faecal excretion. Animals received $5 \mathrm{~g}$ of $\mathrm{Cr}_{2} \mathrm{O}_{3} \mathrm{~d}^{-1}$. The marker supply, the adaptation period and faeces collection followed the methodology described by (KOZLOSKI et al., 2006). On the same occasion to reduce animal management in the faeces collection days, they received a polyethylene external marker, with different colors for each animal to identify faeces on grassland. The polyethylene external marker was made with plastic A4 sheets of $0.3 \mathrm{~mm}$ thickness, using a manual machine binder (Excentrix) with $4 \mathrm{~mm}$ diameter. The $\mathrm{Cr}_{2} \mathrm{O}_{3}$ supply started when animals were moved to representative paddocks considering fecal collection period. For collections, daily "sweeps" on paddocks were performed and if the polyethylene marker was present, samples were collected for each animal replicate. The standard curve was prepared with $100 \mathrm{mg}$ of $\mathrm{Cr}_{2} \mathrm{O}_{3}$ Fecal production (FP) was estimated as follows: $\mathrm{FP}=$ supplied $\mathrm{Cr}_{2} \mathrm{O}_{3}\left(\mathrm{~g} \mathrm{~d}^{-1}\right) /$ feces $\mathrm{Cr}_{2} \mathrm{O}_{3}(\mathrm{~g}$ $\left.\mathrm{kg}^{-1} \mathrm{DM}\right)$. Then, the intake estimation was calculated as follows: Intake $\left(\mathrm{g} \mathrm{day}^{-1}\right)=\mathrm{FP}\left(\mathrm{g} \mathrm{d}^{-1}\right) /(1$-degradability).

Results were analyzed with ANOVA and F-test at 0.05 significance level and 0.10 was considered as tendency. Differences between means were determined using the Tukey test for multiple comparisons, using the PROC MIXED model procedure, including the fixed effects of treatments, periods and the interaction treatment $\times$ period using, whereas animal group was a random effect from SAS (Statistical Analysis System, version 9.3). Period was considered a repeated measure and best covariance structure chosen according to smallest Bayesian Information Criteria.

\section{RESULTS}

An interaction between the effects of treatments and period $(\mathrm{P}<0.05)$ was observed for average daily gain (ADG). Heifers in $375 \mathrm{DD}$ treatment presented an increase along the evaluation periods. Conversely, heifers' ADG in 750 DD presented a fluctuation along the periods (Table 1), showing the lowest ADG in period 2 and highest in period 3. In addition, both management strategies resulted in similar ADG just in periods $4(\mathrm{P}<0.01)$. In contrast, heifers in 750 DD showed $64 \%$ higher $\mathrm{ADG}(\mathrm{P}<0.05)$ compared to heifers in 375 DD during period 3 (Table 1).

Mean stocking rate (MSR) differed $(\mathrm{P}<0.05)$ between treatments and periods (Table 2). MSR was 
Table 1 - Treatments $\times$ periods interactions of the average daily gain of heifers $\left(\mathrm{kg}_{\mathrm{gnimal}}{ }^{-1} \mathrm{~d}^{-1}\right)$ grazing a natural grassland subjected to two thermal sums determining the rest intervals ( 375 and 750 degree-days).

\begin{tabular}{|c|c|c|c|c|c|c|c|c|}
\hline \multirow{2}{*}{ Treatments (DD) } & \multicolumn{5}{|c|}{ 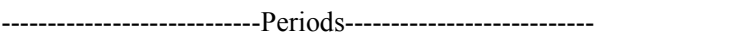 } & \multicolumn{3}{|c|}{ 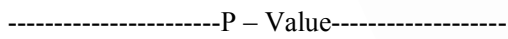 } \\
\hline & 1 & 2 & 3 & 4 & SEM & Treat & Per & Treat $\times$ Per \\
\hline 375 & $0.058^{\mathrm{A}}$ & $0.323^{\mathrm{A}}$ & $0.358^{\mathrm{B}}$ & $0.413^{\mathrm{A}}$ & \multirow{2}{*}{0.0438} & \multirow{2}{*}{0.674} & \multirow{2}{*}{0.0001} & \multirow{2}{*}{0.0048} \\
\hline 750 & $0.157^{\mathrm{A}}$ & $0.087^{\mathrm{B}}$ & $0.554^{\mathrm{A}}$ & $0.332^{\mathrm{A}}$ & & & & \\
\hline
\end{tabular}

$25 \%$ higher in $375 \mathrm{DD}$ compared to $750 \mathrm{DD}$; however, this difference could be partly attributed to the fact that the treatment $750 \mathrm{DD}$ has a larger area (33\% higher) per repetition.

Total beef production gain per area (BPA) was similar between treatments $(\mathrm{P}<0.01)$. Instantaneous stocking rate (ISR) was similar between treatments, been different just for periods $(\mathrm{P}<0.05)$, showing an increase along the trial (Table 2).

There is difference between periods $(\mathrm{P}<0.05)$ for feed intake $(\mathrm{FI})$, decreasing from the first to the second period (Table 2). The intake of ground corn (GCI) increased $8 \%$ between period 1 and $4(\mathrm{P}<0.05)$, it was due to animal gain along the periods. The protein supplementation intake (PSI) was similar among periods. Estimations of nutritional value (Table 2) did not present a significant treatment $\times$ period interaction $(\mathrm{P}>0.05)$. Crude protein $(\mathrm{CP})$ concentration was similar among treatments $(\mathrm{P}>0.05)$ and it was $35 \%$ greater in period 3 compared to periods 1,2 and $4(\mathrm{P}<0.05)$. In situ organic matter degradability (ISOMD) had a similar trend to $\mathrm{CP}$ with increasing values over the period 3 being $14.5 \%$ greater than period 1 and $2(\mathrm{P}<0.05$ and $\mathrm{P}<0.01)$. Neutral detergent fiber (NDF) was similar among treatments and increased sharply from period 1 to 2 $(\mathrm{P}>0.01)$. Acid detergent fiber (ADF) was not affected by treatments or periods ( $\mathrm{P}>0.05$; Table 2$)$. Ground corn supplement had $86.7 \mathrm{~g} \mathrm{~kg}^{-1}$ of $\mathrm{CP}, 935.7 \mathrm{~g} \mathrm{~kg}^{-1}$ of ISOMD and $198.7 \mathrm{~g} \mathrm{~kg}^{-1}$ of NDF.

Sward morphological components was mostly similar amongst treatments and periods $(\mathrm{P}>0.05)$. Green leaf mass was $1108 \mathrm{~kg} \mathrm{ha}^{-1}$ of $\mathrm{DM}$, stem mass was $105 \mathrm{~kg} \mathrm{ha}^{-1}$ of DM and dead material mass was $2388 \mathrm{~kg} \mathrm{ha}^{-1}$ of $\mathrm{DM}(\mathrm{P}>0.4)$. No interactions between treatments and periods or differences between

Table 2 - Variables of animal production, feed intake and forage value of hand-plucked samples of heifers grazing a natural grassland subjected to two thermal sums determining the rest intervals ( 375 and 750 degree-days).

\begin{tabular}{|c|c|c|c|c|c|c|c|c|c|c|}
\hline \multirow{2}{*}{ Items } & \multicolumn{2}{|c|}{---Treats (DD)--- } & \multirow{2}{*}{ SEM } & \multicolumn{4}{|c|}{ - } & \multirow{2}{*}{ SEM } & \multicolumn{2}{|c|}{-----P- Value----- } \\
\hline & 375 & 750 & & 1 & 2 & 3 & 4 & & $\mathrm{~T}$ & $P$ \\
\hline Initial $\mathrm{BW}^{1}$ & 221 & 219.1 & 3.31 & $220.0^{\mathrm{D}}$ & $223.0^{\mathrm{C}}$ & $228.6^{\mathrm{B}}$ & $241.8^{\mathrm{A}}$ & 1.99 & 0.856 & 0.000 \\
\hline Final BW ${ }^{1}$ & 252.6 & 251.3 & 2.83 & $223.0^{\mathrm{D}}$ & $228.7^{\mathrm{C}}$ & $241.8^{B}$ & $251.9^{\mathrm{A}}$ & 2.08 & 0.867 & 0.000 \\
\hline $\mathrm{MSR}^{2}$ & 931.2 & 695.9 & 9.03 & $775.5^{\mathrm{D}}$ & $790.9^{C}$ & $823.8^{\mathrm{B}}$ & $864^{\mathrm{A}}$ & 6.60 & 0.002 & 0.000 \\
\hline $\mathrm{BP}^{2}$ & 147.7 & 144.8 & 1.66 & $14^{\mathrm{D}}$ & $20.78^{\mathrm{C}}$ & $62.33^{\mathrm{A}}$ & $49.10^{\mathrm{B}}$ & 1.90 & 0.889 & 0.000 \\
\hline $\mathrm{ISR}^{2}$ & 2793 & 2783 & 33.2 & $2658^{\mathrm{D}}$ & $2710^{\mathrm{C}}$ & $2823^{\mathrm{B}}$ & $2962^{\mathrm{A}}$ & 24.99 & 0.852 & 0.000 \\
\hline $\mathrm{FI}^{3}$ & 23.8 & 26.7 & 0.120 & - & $26.7^{\mathrm{A}}$ & - & $22.8^{\mathrm{B}}$ & 0.087 & 0.229 & 0.008 \\
\hline $\mathrm{GCI}^{4}$ & 1.11 & 1.13 & 0.014 & $1.10^{\mathrm{B}}$ & $1.11^{\mathrm{B}}$ & $1.14^{\mathrm{B}}$ & $1.19^{\mathrm{A}}$ & 0.010 & 0.669 & 0.002 \\
\hline $\mathrm{PSI}^{4}$ & 0.232 & 0.283 & 0.030 & 0.253 & 0.218 & 0.295 & 0.264 & 0.042 & 0.321 & 0.679 \\
\hline $\mathrm{CP}^{5}$ & 97.0 & 91.0 & 0.53 & $82.0^{\mathrm{B}}$ & $87.0^{\mathrm{B}}$ & - & $115.0^{\mathrm{A}}$ & 0.97 & 0.442 & 0.011 \\
\hline $\mathrm{OMISD}^{5}$ & 587.0 & 568.0 & 1.38 & $538.0^{\mathrm{B}}$ & $564.0^{\mathrm{B}}$ & - & $631.0^{\mathrm{A}}$ & 2.66 & 0.371 & 0.008 \\
\hline $\mathrm{NDF}^{5}$ & 689.0 & 607.0 & 4.59 & $485.0^{\mathrm{B}}$ & $724.0^{\mathrm{A}}$ & - & $736.0^{\mathrm{A}}$ & 6.26 & 0.238 & 0.016 \\
\hline $\mathrm{ADF}^{5}$ & 326.0 & 329.0 & 3.03 & 281.0 & 359.0 & - & 339.0 & 3.21 & 0.984 & 0.343 \\
\hline
\end{tabular}

BW - Body weight; MSR - Mean stock rate; BP - Beef production; ISR - Instantaneous stock rate; FI - Feed intake (forage plus supplements); GCI - Ground corn intake; PSI - Protein supplement intake; CP - Crude protein; OMISD - Organic matter in situ degradability; NDF - Neutral detergent fiber; ADF - Acid detergent fiber. ${ }^{1} \mathrm{Kg} ;{ }^{2} \mathrm{~kg} \mathrm{BW} \mathrm{ha}{ }^{-1} ;{ }^{3} \mathrm{~g} \mathrm{~kg}^{-1} \mathrm{~d}^{-1}$ of body weight; ${ }^{4} \mathrm{~kg}$ animal ${ }^{-1}$ day ${ }^{-1}$; ${ }^{5} \mathrm{~g} \mathrm{~kg}^{-1}$ of dry matter. Means followed by different letters in the row differ by Tukey's test $(\mathrm{P}<0.05)$ 
periods were observed. Only stem mass had difference amongst periods $(\mathrm{P}<0.05)$ with higher values in periods 1 and 3 (134 and 142kg DM ha ${ }^{-1}$, respectively) compared to periods 2 and 4 (89 and $57 \mathrm{~kg} \mathrm{DM} \mathrm{ha-1,}$ respectively), but it represents less than $4 \%$ of total above ground biomass all over the trial.

Dead material did not differ among treatments or periods $(\mathrm{P}>0.05)$, and represents a mean of $65 \%$ of DM. Other plant species mass (than Poaceae) tended to be greater in 375 DD compared to $750 \mathrm{DD}(\mathrm{P}<0.10)$ but also represents less than $4 \%$ of overall biomass, which not presented significant differences amongst periods (overall average of $117 \mathrm{~kg}$ $\left.\mathrm{DM} \mathrm{ha}^{-1}\right)$. Herbage allowance was similar amongst treatments and periods $(\mathrm{P}>0.10)$ with a mean of $100 \mathrm{~g}$ $\mathrm{DM} \mathrm{kg}{ }^{-1}$ body weight.

\section{DISCUSSION}

Limitations to young cattle performance along cool season in natural grasslands were due to low forage quality that is a consequence of lower temperatures and frosts that inhibit $\mathrm{C} 4$ grasses growth. These species contributed to the major part of available herbage mass (65 to $80 \%$ ) according to QUADROS et al. (2011), but in this trial, it represents more than $93 \%$, considering dead material as not available. GARAGORRY et al. (2008) recorded crude protein and in situ organic matter degradability in natural grassland of respectively, 6.2 and $29.8 \%$ during cool season.

Sward structural components (leaf mass, stem mass and dead material mass) did not differ among the treatments in the present study. Dead material was near $65 \%$ of total HM, which could be to lower temperatures, while BARBIERI et al. (2015) found $44 \%$ of dead material on HM during warm season. The high percentage of dead material recorded may be attributed to sample procedures in both trials, as tussocks were also sampled, unlike PINTO et al. (2007), that sampled just among tussocks. Herbage mass reported by these authors is almost 2.5 times less than those obtained in this trial. Therefore, the higher percentage of dead material recorded could be also attributed to include tussocks in sampling.

QUINTANS et al. (1994) recorded body weight loss of $0.253 \mathrm{~kg}_{\text {animal }}{ }^{-1} \mathrm{~d}^{-1}$ in natural grassland with heifers of same age, without supplementation and has obtained average daily gain of $0.161 \mathrm{~kg}$ animal ${ }^{-1} \mathrm{~d}^{-1}$, with a rate of $100 \mathrm{~g} \mathrm{~kg}^{-1}$ of body weight of whole rice. The present study found positive ADG values which could be attributed to the nutritional attributes of hand-plucked herbage samples, similar to that selected by heifers, to the non-limiting herbage availability and to supplementation provided in the present study, besides that the dry material percentage was of $65 \%$ of the HM, $13 \%$ less than that recorded by QUINTANS et al. (1994).

VAN SOEST (1994) suggested CP concentrations below $7 \%$ of DM limit growth of rumen microorganisms changing feed digestibility and intake. The CP values from the hand-plucked samples recorded in this trial are above such CPlimiting values, which could indicate that the observed ADG are not only due to the supplements. The CP values of the present study were also higher than those reported by OSPINA \& MEDEIROS (2003) in similar grassland and similar to those of BARBIERI et al. (2015) during spring/summer at the same experimental site. As expected, ADG was greater in periods 3 and 4 compared to periods 1 and 2, in agreement with higher $\mathrm{CP}$ and digestibility values.

GONÇALVES et al. (2007) reported greater $\mathrm{ADG}, 0.550 \mathrm{~kg}$ animal ${ }^{-1} \mathrm{~d}^{-1}$ compared to the present study when supplementing heifers with whole rice bran at $50 \mathrm{~g} \mathrm{~kg}^{-1}$ of body weight in a natural grassland. However, heifers in those studies were supplemented from February to June whereas the critical period for animal production in Pampa biome grasslands ranges from June to late August.

FONTOURA JÚNIOR et al. (2007), CRANCIO et al. (2006) and SOARES et al. (2005) reported body weight loss in heifers and steers during the cool season with herbage allowances of 80 and $140 \mathrm{~g} \mathrm{DM} \mathrm{kg}^{-1}$ of body weight under continuous grazing. The herbage allowance (from leaves) in this trial was in average of $100 \mathrm{~g} \mathrm{DM} \mathrm{kg} \mathrm{gody}^{-1}$ weight in both treatments, it value is 3 to 4 times the intake potential, considered non-limiting to feed intake of the animals (SOLLENBERGER et al., 2005).

Nevertheless, calves and heifers also lost weight in the same experimental area and treatments with just protein supplementation $\left(450 \mathrm{~g} \mathrm{~kg}^{-1} \mathrm{CP}\right.$ from urea) during the cool season (QUADROS et al., 2011). According to SOARES et al. (2005); MOOJEN \& MARASCHIN (2002); NABINGER et al. (2000) the Pampa natural pastures allows body weight gains above $0.5 \mathrm{~kg}$ animal ${ }^{-1} \mathrm{~d}^{-1}$ during the warm season without hydric deficit. In the cool season, most heifers rearing production systems based on natural grasslands presents weight loss as the $20 \%$ of body weight loss reported by QUINTANS et al. (1994). In this; however, recorded mean value of $0.285 \mathrm{~kg}$ animal ${ }^{-1} \mathrm{~d}^{-1}$ represented $57 \%$ of the gain in the favorable season above mentioned. This daily growth rate could allow mating heifers at 24 months 
old $(60 \%$ of mature body weight; NRC, 1996) which is one of the primary goals in cow-calf operations of southern Brazil.

Production per area in the present study was higher than the $45 \mathrm{~kg} \mathrm{ha}^{-1}$ reported by SOARES et al. (2005) and five times the mean beef production per area (BPA) during the cool season in Rio Grande do Sul (NABINGER et al., 2000). The higher BPA of the present study could be attributed to the best nutritional value of herbage and to supplementation that allowed higher stocking rate.

Mean stocking rate was two-fold higher in the present study compared to values reported by FONTOURA JÚNIOR et al. (2007); NEVES et al. (2009); SOARES et al. (2005), and similar to cool season annual pastures (POTTER et al., 2010). Similar stocking rate were achieved by QUADROS et al. (2011) and BARBIERI et al. (2015) using the same experimental protocol. Therefore, stocking rate of the present study could be regarded as high and could be attributed to high leaf mass, herbage mass and leaf allowance. Natural grasslands supporting higher stocking rates, while achieving ADG appropriate for mating heifers at 24 months of age, produces gain per area to make livestock production economically competitive with other agricultural land uses (QUADROS et al., 2011).

Pre-grazing herbage mass was similar among the treatments, unlike data from QUADROS et al. (2011) and BARBIERI et al. (2015). These authors reported significant differences in the pre-grazing herbage mass amongst treatments using a similar protocol (same thermal accumulation rest intervals) to the present study. The lack of difference amongst treatments in the present study could be due to a forage deferring period of 45 days before the experimental period. Herbage mass from this trial was higher than the HM reported by MARASCHIN (1998), MOOJEN \& MARASCHIN (2002) in trials with fixed herbage allowances during the spring and summer pasture growing season. SOARES et al. (2005); (PINTO et al., 2008) and (MEZZALIRA et al., 2012) reported HM values 2.2 times lower compared to the present study when evaluating natural grasslands with similar grasses functional groups composition and combining variable herbage allowance across seasons ( 80 to $120 \mathrm{~g} \mathrm{~kg}^{-1}$ of BW), considering this combination the best for beef production.

The same herbage allowance among treatments could explain the similar ADG, that according to NABINGER et al. (2009) the optimal animal performance (individual and per area) was found with herbage allowance between 115 to $135 \mathrm{~g} \mathrm{~kg}^{-1}$ of body weight. The herbage allowance recorded was a consequence of the grazing methodology, rotational grazing system. In this system, grazing intervals of grazing followed by removal of animals to allow similar recover periods for all tillers in the pasture. This plant regrowth strategy are often used and could have profound effects on quantity and quality of pasture regrowth and what is available to the grazing animal (HUMPHREYS, 1991; LEMAIRE et al.,2009). VIRGONA et al. (2000) reported higher herbage mass and frequency of desirable species on rotational grazing system, similar during dry and cool season; therefore, this grazing system increases available forage quality.

\section{CONCLUSION}

Using grasses' morphogenic traits based strategies to determine the rest intervals in a rotational grazing system allows higher stocking rate when combined with low supplementation rate during the cool season. These strategies could accomplish heifers' growth rate to reach a target body weight for mating at 24 months, improving beef cattle production in natural grasslands.

\section{BIOETHICS AND BIOSSECURITY COMMITTEE APPROVAL}

All procedures in this study were performed in accordance to Registration Protocol approved by the Comitê de Ética em Uso de Animais na Universidade Federal de Santa Maria.

\section{ACKNOWLEDGEMENTS}

We thank to Conselho Nacional de Desenvolvimento Científico e Tecnológico (CNPq) and Coordenação de Aperfeiçoamento de Pessoal de Nível Superior (CAPES), (Ministry of Education of Brazil).

\section{REFERENCES}

BARBIERI, C. W. et al. Beef heifers grazing behavior and herbage intake in natural grassland under rotational grazing. Ciência Rural, vol.45, n.11, p.2056-2062, 2015. Available from: <http://www. scielo.br/pdf/cr/v45n11/1678-4596-cr-0103_8478cr20141227>. Accessed: Jul. 24, 2016. doi: 10.1590/0103-8478cr20141227.

CONFORTIN,A.C.C. et al. Structural and morphological characteristics of black oats and Italian ryegrass on pasture submitted to two grazing intensities. Revista Brasileira de Zootecnia, v.39, p. 2357 - 2365, 2010. Available from: <http://www.scielo.br/scielo.php?script=sci_ arttext\&pid $=$ S1516-35982010001100007\&lng=en\&nrm=iso $>$. Accessed: Jun. 04, 2015. doi: 10.1590/S1516-35982010001100007.

CRANCIO, L. A. et al. Heifers weight gain on Serra do Sudeste native pasture in RS, submitted to undesirable plants control and grazing intensities. Ciência Rural, v.36, p.1265-1271, 2006. Available from: $<$ http://www.scielo.br/scielo.php?script=sci_abstract\&pid=S0103- 
84782006000400034\&lng=en\&nrm=iso\&tlng=en>. Accessed: Jul. 13, 2016. doi: 10.1590/S0103-84782006000400034.

CRUZ, P. et al. Leaf trais as functional descriptors od the intensity of continuous grazing in native grassland in the South of Brazil. Randeland Ecology \& Management, v.63, n.3, p.350-358, 2010. doi: 10.2111/08-016.1.

EGGERS, L. et al. Plyllochron of Paspalum notatum and Coelorhachis selloana (HACK.) camus in pasture. Scientia Agricola, v.61, n.4, p.353-357, 2004. Available from: <http://www.revistas.usp.br/ sa/article/viewFile/21923/23947>. Accessed: Jun. 21, 2014. doi: 10.1590/S0103-90162004000400001.

FONTOURA JÚNIOR, J. A. S. et al. Animal production on native pasture submitted to the control of undesirable plants and grazing intensity. Ciência Rural, v.37, n.1, p.247-252, 2007. Available from: $<$ http://www.scielo.br/scielo.php?script $=$ sci_arttext\&pid=S0103$84782007000100040 \& \operatorname{lng}=\mathrm{en} \& \mathrm{nrm}=\mathrm{iso}>$. Accessed: Jun. 12, 2016. doi: $10.1590 / \mathrm{S} 0103-84782007000100040$.

GARAGORRY, F. C. et al. 2008. Produção animal em pastagem natural e pastagem sobressemeada com espécies de estação fria com ou sem o uso de glyphosate. Acta Scientiarum, v.30, n.2, p.127134,2008 .

GONÇALVES, M. B. F. et al. Beef steers performance in natural pasture with levels of full fat rice brain supplementation. Ciência Rural, v.37, n.2, p.476-481, 2007. Available from: <http://www.scielo.br/ scielo.php?script $=$ sci_arttext\&pid $=$ S0103-84782007000200028\&ln $\mathrm{g}=\mathrm{en} \& \mathrm{nrm}=\mathrm{iso}>$. Accessed: May. 15, 2016. doi: 10.1590/S010384782007000200028 .

HASENACK, H. et al. Mapa de sistemas ecológicos da ecorregião das savanas uruguais em escala 1:500.000 ou superior e relatório técnico descrevendo insumos utilizados e metodologias de elaboração do mapa de sistemas ecológicos. Porto Alegre: UFRGS. Centro de Ecologia, 2010. 17 p. (Relatório Técnico Projeto UFRGS/TNC, 4.).

HODGSON, J.; DA SILVA, S. C. Sustainability of grazing systems: goals, concepts and methods. In: LEMAIRE, G.; HODGSON J; MORAES, A; CARVAlHO, P. C. F; NABINGER, C. (Eds.) Grassland ecophysiology and grazing ecology. CABI Publishing, CAB International, Wallingford, Oxon OX10 8DE, UK, 1-14. 2000

HUMPHREYS, R.L. Tropical Pasture Utilization. Cambridge University Press, pp. 220. 1991.

IBGE - Instituto Brasileiro de Geografia e Estatística. Mapa da vegetação do Brasil e Mapa de Biomas do Brasil. 2004. Available from: $<$ http://www.ibge.gov.br/home/geociencias/default_prod.shtm\#USO $>$. Acessed: May. 12, 2014

KOZLOSKI, G.V. et al. Uso de óxido de cromo como indicador da excreção fecal de bovinos em pastejo: variação das estimativas em função do horário de amostragem. Ciência Rural, v.36, n.2, p.599-603, 2006. Available from: $<\mathrm{http} / / \mathrm{www}$.scielo.br/scielo.php?script=sci art text\&pid=S0103-84782006000200037>. Accessed: May 12, 2013. doi: $10.1590 / \mathrm{S} 0103-84782006000200037$.

LEMAIRE, G. et al. Interactions between leaf lifespan and defoliation frequency in temperate and tropical /pastures: a review. Grass and Forage Science, v. 64, p. 341-353, 2009.

MACHADO, J. M. et al. Morphogenesis of native grasses of Pampa Biome under nitrogen fertilization. Revista Brasileira de Zootecinia, v.42, p.22-29, 2013. Available from: <http://www.scielo.br/scielo. php? script $=$ sci arttext\&pid $=$ S1516-35982013000100004\&lng $=$ en\&nrm=iso $>$. Accessed: Feb. 13, 2015. doi: 10.1590/S151635982013000100004 .

MARASCHIN, G.E. Utilização, manejo e produtividade das pastagens nativas da região sul do Brasil. p.29-39, 1998. In: Ciclo de palestras em produção e manejo de bovinos de corte. ed. ULBRA.

MEZZALIRA, J. C. et al. Animal and vegetal production of a natural pasture under different forage allowances for cattle. Ciência Rural, vol.42, p.1264-1270. 2012. Available from: <http://www.scielo.br/ scielo.php?script $=$ sci abstract\&pid $=$ S0103-84782012000700021\&ln $\mathrm{g}=\mathrm{en} \& \mathrm{nrm}=\mathrm{iso} \& \operatorname{lng}=\mathrm{en}>$. Accessed: Oct. 25, 2017. doi: 10.1590/ S0103-84782012005000039.

MOOJEN, E, L.; MARASCHIN, G. E. Potential production of a southern Brazil rangeland submitted to forage on offer levels. Ciência Rural, v.32 p.127-132, 2002. Available from: <http://www.scielo.br/ scielo.php?script $=$ sci_abstract\&pid $=$ S0103-84782002000100022\&ln g=pt\&nrm=iso\&tlng=en>. Accessed: Oct. 25, 2017. doi: 10.1590/ S0103-84782002000100022.

NABINGER, C. et al. Campos in Southern Brazil. In: LEMAIRE, G. et al. Grassland ecophysiology and grazing ecology. Wallingford: CABI Publishing. p. 355-376. 2000.

NABINGER, C. et al. Produção animal com base no campo nativo: aplicações de resultados de pesquisa. In: PILLAR, V. D. et al (Ed.). Campos Sulinos, conservação e uso sustentável da biodiversidade. Brasilia: MMA. Brasilia: Ministério do Meio Ambiente, 2009. Cap. 13, p. 175-198.

NEVES, F.P. et al. Herbage allowance management strategies to raise beef heifers on natural pastures. Revista Brasileira de Zootecnia, v.38, p.1532-1542, 2009. Available from: <http://www.scielo.br/ scielo.php?script=sci_arttext\&pid=S1516-35982009000800018\&ln $\mathrm{g}=\mathrm{pt} \& \operatorname{tlng}=\mathrm{pt}>$. Accessed: Mar. 22, 2016. doi: 10.1590/S151635982009000800018 .

NRC - Nutrient Requirements of Beef Cattle. National Academies Press. $7^{\text {th }}$ ed. Waschinton, USA, 1996. Available from: <www.nap. edu/catlog/9791.html>. Accessed: Mar. 12, 2016.

ORSKOV, E.R.; MCDONALD, I. The estimation of protein degradability in the rumen from incubation measurements weighted according to rate of passage. Journal Agricultural Science, v.92, p. 499-503, 1979.

OSPINA, H. P.; MEDEIROS, F. S.; 2003. Suplementação a pasto: uma alternativa para produção de novilhos precoce. p.83-115, 2003. In: Simpósio internacional da carne bovina: da produção ao mercado consumidor.

PINTO, C.E. et al. Primary and secondary production in a natural pasture submitted to different herbage allowances at the "Depressão Central", Rio Grande do Sul. Revista Brasileira de Zootecnia, v.37, p.1737-1741, 2008. Available from: <http://www.scielo.br/scielo.php?script=sci arttext\&pid=S1516-35982008001000004\&lng-pt\&tlng=pt $>$. Accessed: Jun. 20, 2015. doi: 10.1590/S1516-35982008001000004.

PÖTTER, L. et al. Concentrate supplementation for beef heifers on coolseason cultivated pastures. Revista Brasileira de Zootecnia, v. 39, p. $992-$ 1001, 2010. Available from: $<$ http://www.scielo.br/scielo.php?script=sci arttext\&pid $=$ S1516-35982010000500008\&lng $=$ en \&nrm $=$ iso $>$. Accessed: Jun. 12, 2015. doi: 10.1590/S1516-35982010000500008. 
QUADROS, F.L.F. de. et al. Uso de tipos funcionais de gramíneas como alternativa de diagnóstico da dinâmica e do manejo de campos naturais. In: Anais da 43" Reunião Anual da Sociedade Brasileira de Zootecnia. Sociedade Brasileira de Zootecnia, João Pessoa, 2006.

QUADROS, F. L. F. de et al. Using morphogenic traits racionality to rotational grazing: experience of agroecological management from Pampa Biome natural grasslands. Cadernos de Agroecologia, v. 6, n. 1, 2011.

QUINTANS, G. et al. Alternativas de suplementación de vaquillonas. Jornada Técnica, v.2: p.2-9, 1994. In: Avances en suplementación de la recría e invernada intensiva. Jornada técnica INIA, Treinta y Tres, Uruguai.

SANTOS,A. B. et al. Nutritive value of Rio Grande do Sul/Brazil's native grasses, ranked according to functional typology under fire and grazing regimes. Ciência Rural, v. 43, n. 2, p. 342-347, 2013. Available from: $<$ http://www.scielo.br/scielo.php?script=sci_abstract\&pid=S0103- 84782013000200025\&lng=pt\&nrm=iso\&tlng=en>. Accessed: Oct. 18, 2016. doi: 10.1590/S0103-84782013000200025.

SOARES, A. B. et al. Animal and forage production on native pasture under different herbage allowance. Ciência Rural, v.35, p.1148-1154, 2005. Available from: $<\mathrm{http} / /$ www.scielo.br/scielo.php?script=sci abstract\&pid=S0103-84782005000500025\&lng=pt\&nrm=iso\&tlng= en>. Accessed: Nov. 13, 2016. doi: 10.1590/S0103-84782005000500025.

SOLLENBERGER, L.E. et al. Reporting forage allowance in grazing experiments. Crop Science, v.45, p.896-900, 2005.

VAN SOEST, P.J. Nutritional ecology of the ruminant. $2^{\text {nd }}$ ed. Cornell University Press. New York, USA, 1994.

VIRGONA M. J. et al. Effects of grazing management on phalaris herbage mass and persistence in summer-dry environments. Australian Journal of Experimental Agriculture, v. 40, p.171-184, 2000. 